\title{
Testicular Cancer Clinical Regional Lymph Nodes TNM Finding v8
}

National Cancer Institute

\section{Source}

National Cancer Institute. Testicular Cancer Clinical Regional Lymph Nodes TNM Finding v8. NCI Thesaurus. Code C140198.

A clinical finding about one or more characteristics of testicular cancer, following the rules of the TNM AJCC V8 classification system as they pertain to staging of regional lymph nodes. 